\title{
CONSOLIDATION OF CARGOS IN THE ROAD TRANSPORT AS A KEY METHOD TO SUCCESS
}

\author{
Zbigniew Lukasik ${ }^{1}$ Aldona Kuśmińska-Fijałkowska ${ }^{1, *}$, Jacek Kozyra1, Sylwia Olszańska² \\ ${ }^{1}$ Faculty of Transport, Electrical Engineering and Computer Science, Kazimierz Pulaski University of Technology \\ and Humanities in Radom, Radom, Poland \\ ${ }^{2}$ Chair of Logistics and Process Engineering, University of Information Technology and Management in Rzeszow, \\ Rzeszow, Poland
}

*E-mail of corresponding author: a.kusminska@uthrad.pl

\section{Resume}

The problem of consolidation of goods for the provider of logistic services, which is a third part that delivers goods from many suppliers to one business client in time horizon was analysed in this article. Every parcel has a fixed date of reception in the source and delivery schedule in a destination. In the age of highly developed economy, time pressure and costs, outsourcing is a condition necessary to improve the functioning of enterprises. New logistic chains, networks of terminals and intermodal connections are built every year to reduce the transport costs and improve the whole process. In this article, the authors presented the benefits resulting from consolidation of cargos in the road transport. Special emphasis was put on determination of the role of the transport costs reduction using the cargo consolidation services.

\section{Article info}

Received 30 March 2020

Accepted 2 June 2020

Online 6 November 2020

\section{Keywords:}

cargo transportation, costs of transport, efficient transportation, system transport planning, consolidation

\section{Introduction}

Large carriers have more potential to survive any crisis. Therefore, the Polish transport industry, analogically to companies in Western Europe, will have to consolidate. Consolidation allows to transport smaller goods (e.g. put on a few pallets) from distant areas for a reasonable price [1-2] Nowadays, time and price are the most important factors; therefore, consolidation of cargos is a good solution [3]. It is also particular facilitation for smaller exporters. Dense network allows combining parcels, both within national and international connections [4]. Moreover, it is a safe form of transport of goods [5]. The consolidation of parcel to one transport means, above all, one shipping order, one parcel number, one customs clearance and one company that deals with transport service [6-8].

The digitization of transport processes can be achieved thanks to the systems of management of transports and invoices or applications monitoring the position of the transport means [9-11]. Programs of the cost optimization are ideal for enterprises having the networks of terminals, which are the most important on the market due to pressure put on the cost reduction [12]. In the last few years, transport business has drastically changed. Due to globalization of economy, range and frequency of transports have considerably increased. New logistic chains, networks of terminals and intermodal connections are built every year [13-15] to reduce the transport costs and improve the whole process. The movement of goods guarantees the functioning of cities and regions, however, motor trucks, due to their size, pace of moving and frequency of stops cause huge difficulties in the road traffic. In addition, they contribute to formation of hold-ups, increased noise and environmental pollution. These difficulties still have a growing trend; therefore, consolidation of cargos in road transport is the future of knowledge-based. Consolidation of cargos is a combination of a few various shipments into one cargo (Figure 1). Such a solution mainly allows optimizing costs. In the event of smaller shipments from a few suppliers (Client A, Client B, Client C), it would be unprofitable to load a few separate pallets. It is also more comfortable for the clients from logistics point of view. All the cargos are delivered within one delivery, which makes end client more satisfied.

A comprehensive analysis of the transport processes efficiency requires a broad view, taking into account both the organizational and financial aspects. The effectiveness analysis is mainly based on use of a set of indicators assessing the transport process [16], bearing in mind the specificity of transport processes in financial and organizational aspects (Tables 1 and 2). In Tables 1 and 2, examples of the rates of assessment of the transport processes effectiveness, from financial (Table 1) and organizational (Table 2) points of view, were presented. Effectiveness of the transport process 


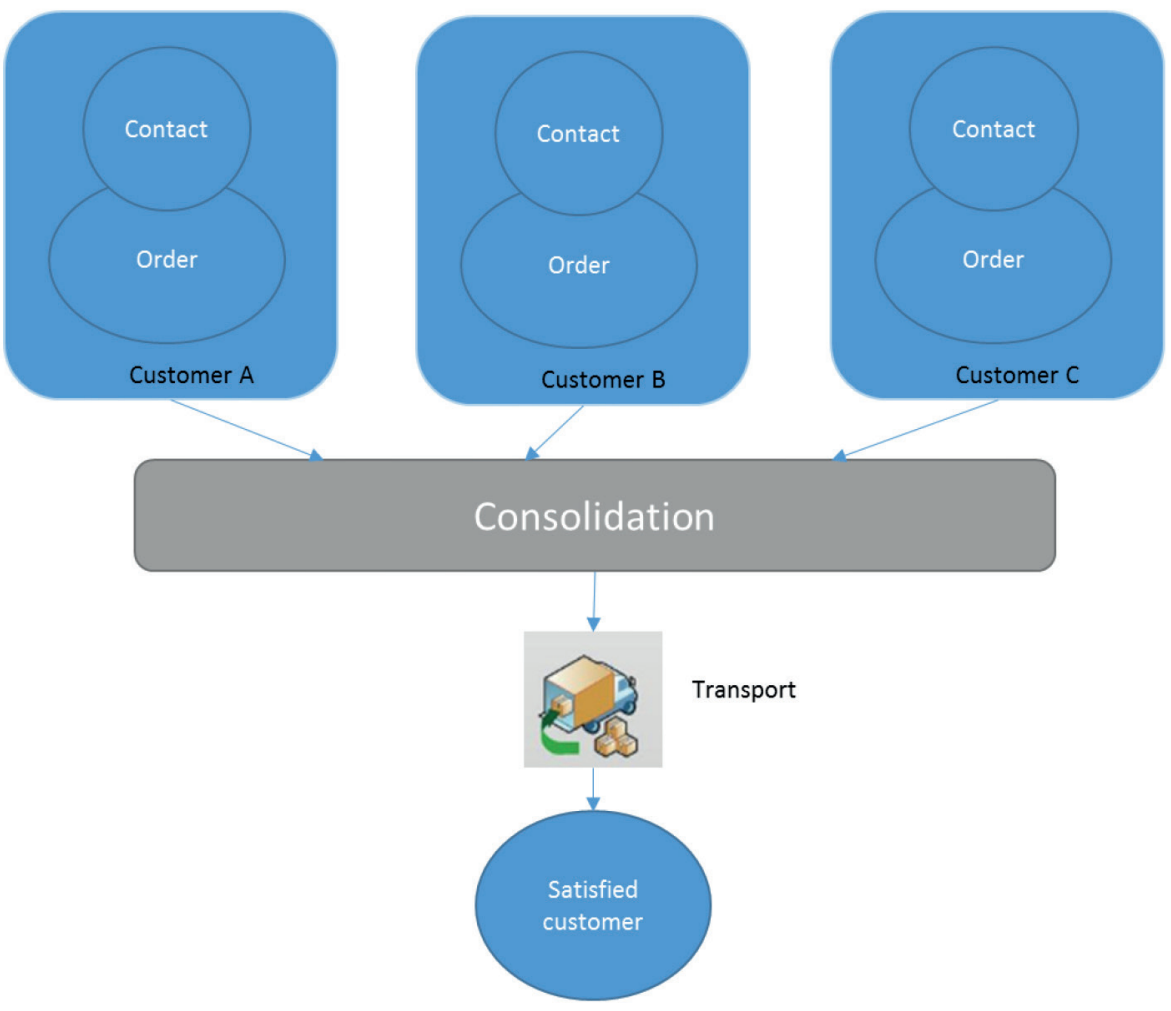

Figure 1 Cargo consolidation

Table 1 Selected indicators for assessing the efficiency of transport processes in organizational terms [16]

\begin{tabular}{|c|c|c|c|}
\hline indicator & formula & characteristics & units of measure \\
\hline load fleet load indicator & & $\begin{array}{l}\text { a - number of kilometers driven, } \\
b \text { - number of means of transport }\end{array}$ & $\mathrm{kg} / \mathrm{car}$ \\
\hline $\begin{array}{l}\text { rate of use of the transport } \\
\text { means }\end{array}$ & $\frac{a}{b}$ & $\begin{array}{l}\text { a- weight of transported load } \\
\text { b- number of means of transport }\end{array}$ & $\mathrm{kg} / \mathrm{car}$ \\
\hline transport intensity index & & $\begin{array}{l}\text { a- transport time, } \\
\text { b- total number of deliveries }\end{array}$ & $\mathrm{h} /$ delivery \\
\hline $\begin{array}{l}\text { timeliness of transport } \\
\text { indicator }\end{array}$ & & $\begin{array}{l}\text { a - number of timely journeys } \\
b \text { - total number of journeys }\end{array}$ & $\%$ \\
\hline $\begin{array}{l}\text { load damage indicator } \\
\text { during the transport }\end{array}$ & $\frac{\mathrm{a}}{\mathrm{b}} \times 100$ & $\begin{array}{l}\text { a - load transported (mass or volume) } \\
\text { b - load capacity or capacity of the transport fleet }\end{array}$ & $\%$ \\
\hline cargo planning & & $\begin{array}{l}\text { a - value of incomplete deliveries } \\
\text { b - value of all deliveries }\end{array}$ & $\%$ \\
\hline
\end{tabular}

is the most visible in a list of meters in the organizational aspect. It is not surprising, because the processes occurring at the operational level have the greatest contribution to the assessment of effectiveness of the transport process.

\section{The consolidation of two means of transport illustrated through an example of client $B$}

The fundamental research goal of the authors of this article was determination of the role of reduction of the transport costs using the consolidation services, illustrated through an example of client B. To achieve the goal, the research and analyses presented were conducted. The client is located in Prague. It now uses two systems of transportation ( $3.5 \mathrm{t}$ and $6 \mathrm{t}$ ) that are sent to specific regions of Germany (Table 3 and Table 4).

In the event if the first means of transport, transit is two days, for the second one, one and a half day (Figure 2 and Figure 3).

Average speed accepted for the analysis of transit is $65 \mathrm{~km} / \mathrm{h}$. LDM a loading meter is the standard unit of measurement for transport by truck. One meter of cargo space, calculated as the product of the total width of the trailer and one meter of length. Most often, the width of the trailer is 2.4 meters, so $1 \mathrm{LDM}-2.4 \mathrm{~m} 2$. LDM calculations can be made using the goodloading.com application. Transport costs based on average rates on the current transport market 
Table 2 Selected indicators for assessing the efficiency of transport processes in financial terms [16]

\begin{tabular}{|c|c|c|c|}
\hline indicator & formula & characteristics & units of measure \\
\hline $\begin{array}{l}\text { shipping costs per } \\
\text { shipment }\end{array}$ & & $\begin{array}{l}\text { a - transport cost } \\
\text { b - number of shipments }\end{array}$ & $€$ \\
\hline $\begin{array}{l}\text { costs of the transport } \\
\text { fleet } i\end{array}$ & $\mathrm{a}$ & $\begin{array}{l}\text { a - cost of kilometers travelled } \\
b \text { - number of means of transport }\end{array}$ & $€ /$ car \\
\hline $\begin{array}{l}\text { costs of the transport } \\
\text { fleet ii }\end{array}$ & $\mathrm{b}$ & $\begin{array}{l}\text { a - value / cost of transported load } \\
b \text { - number of means of transport }\end{array}$ & $€ /$ car \\
\hline transport costs per tkm & & $\begin{array}{l}\text { a - transport cost } \\
\text { b - number of tkm }\end{array}$ & $€ /$ tkm \\
\hline $\begin{array}{l}\text { complaints and returns } \\
\text { valuable incompleteness } \\
\text { of supply }\end{array}$ & $\frac{\mathrm{a}}{\mathrm{b}} \times 100$ & $\begin{array}{l}\text { a - value / cost of returns complaints } \\
\text { b - value / cost of all supplies of materials and raw materials } \\
\text { a - value of incomplete deliveries } \\
\text { b - value of all deliveries }\end{array}$ & $\%$ \\
\hline
\end{tabular}

Table 3 Transport schedule of client B - means of transport no. 1 - 3.5-ton

\begin{tabular}{|c|c|c|c|c|c|c|c|}
\hline code & city & date & time & distance & $\begin{array}{l}\text { working } \\
\text { time }\end{array}$ & $\begin{array}{l}\text { driving } \\
\text { time }\end{array}$ & comment \\
\hline 33098 & Paderborn & 2.07 & 08:00-09:00 & 0 & 1 & 0 & loading \\
\hline 37001 & Gottingen & 2.07 & 11:00-12:00 & 135 & 3 & 2 & \\
\hline 38440 & Wolfsburg & 2.07 & 14:00-15:00 & 135 & 5 & 4 & $\begin{array}{l}45 \text { min pause on the way to } \\
\text { Potsdam }\end{array}$ \\
\hline 14467 & Potsdam & 2.07 & 19:00-20:00 & 205 & 10 & 9 & pause 11 hours \\
\hline 8001 & Zwickau & 3.07 & $11: 30-12: 30$ & 278 & 4.5 & 4.5 & start 7:00 \\
\hline 1099 & Dresden & 3.07 & 15:00-16:00 & 116 & 8 & 6.5 & \\
\hline 10000 & Prague & 3.07 & $18: 30$ & 149 & 10.5 & 9 & unloading \\
\hline
\end{tabular}

Table 4 Transport schedule of client B - means of transport no. 2 - 6-ton

\begin{tabular}{|c|c|c|c|c|c|c|c|}
\hline code & city & date & time & distance & $\begin{array}{l}\text { working } \\
\text { time }\end{array}$ & $\begin{array}{l}\text { driving } \\
\text { time }\end{array}$ & comment \\
\hline 36001 & Fulda & 2.07 & 08:00-09:00 & 0 & 0 & 1 & loading \\
\hline 68159 & Mannheim & 2.07 & 12:00-13:00 & 187 & 4 & 3 & \\
\hline 76131 & Karlsruhe & 2.07 & $14: 00-15: 00$ & 68 & 5 & 4 & $\begin{array}{c}\text { pause } 45 \text { min on the way to } \\
\text { Augsburg }\end{array}$ \\
\hline 86150 & Augsburg & 3.07 & $19: 30-20: 30$ & 228 & 10.5 & 9 & pause 11 hours \\
\hline 93047 & Ratisbon & 3.07 & 10:00-11:00 & 146 & 2 & 2 & start 8:00 \\
\hline \multirow[t]{2}{*}{10000} & Prague & 3.07 & 16:00 & 268 & 8 & 6 & $\begin{array}{c}\text { pause } 45 \text { minutes unloading on } \\
\text { the way }\end{array}$ \\
\hline & & & & 897 & & & \\
\hline
\end{tabular}

and consolidation tariff of the company (Table 5). The cost of every additional place of the so-called stop is $25 €$.

The first means of transport must cover $1018 \mathrm{~km}(0.65$ $€ / \mathrm{km})$, stopping in five places (125€), generating the costs of $786.7 €$. The second means of transport will cover $897 \mathrm{~km}$ $(0.8 € / \mathrm{km})$ and will stop in four additional loading places $(100 €)$. In this case, freight rate is $817.6 €$.

The utilization of both means of transport stays within the range of $86 \%$ (Tables 5-7).

Transport enterprise offers delivery of every cargo within 2 working days. In this case, the cargo loaded on
02/07 shall be available for reception in the warehouse only on 04/07 (Tables 8 and 9).

The cargo will be ready on $4^{\text {th }}$ of July at $9 \mathrm{pm}$ (Table 10). The means of transport that will take goods must be 24-ton and will have to cover $300 \mathrm{~km}$. According to a price list, the rate for such distance is $1.3 € / \mathrm{km}$ (Table 5). Therefore, the cost of this transport will be $390 €$.

Transit will last two and a half days, that is, one day longer than now (Figure 4).

Using defined weight tariff that verifies the costs of transport of cargos to the warehouse in Nuremberg in 


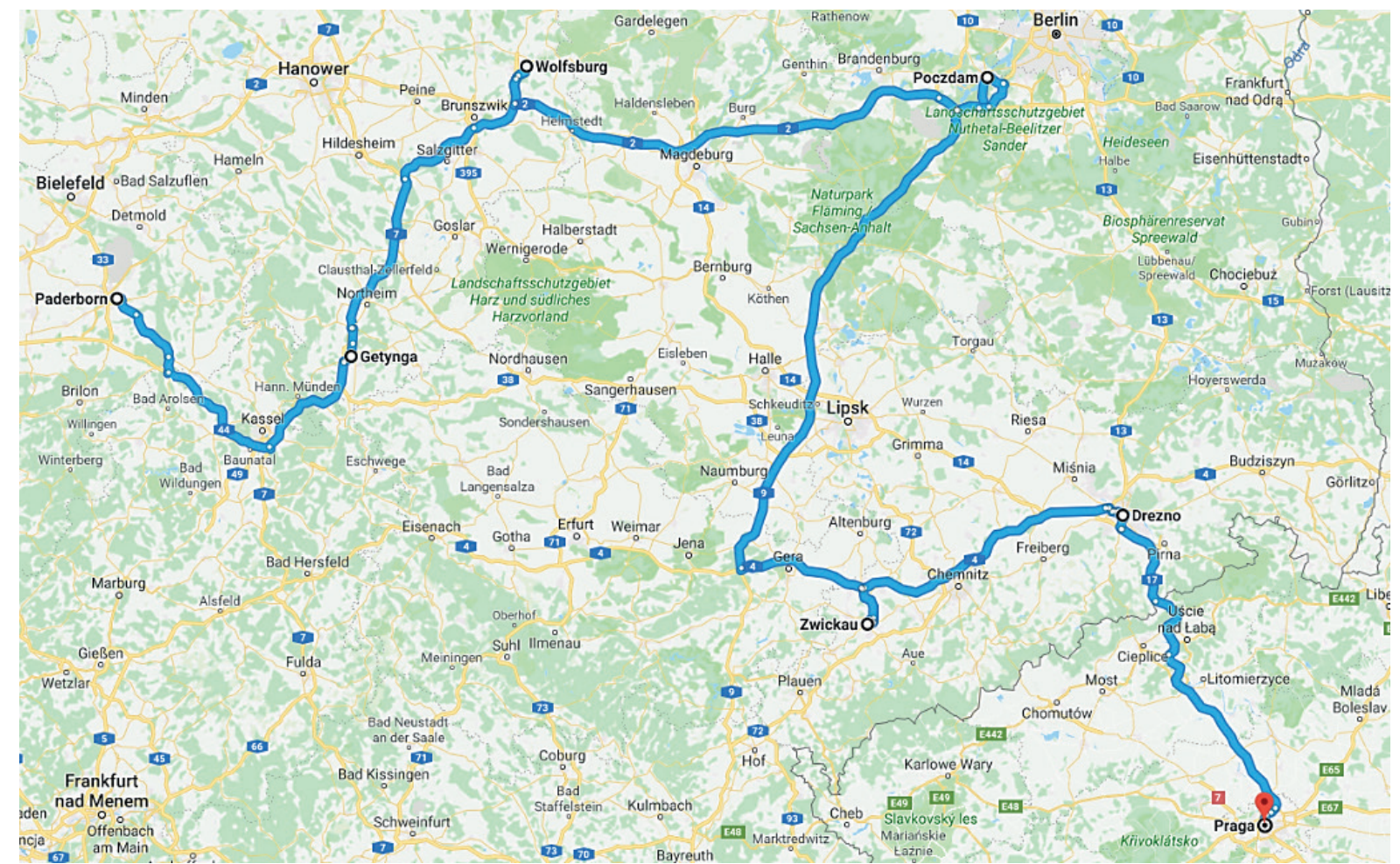

Figure 2 Current organization of transport of a client B - means of transport no. 1 (based on Google Maps pl)

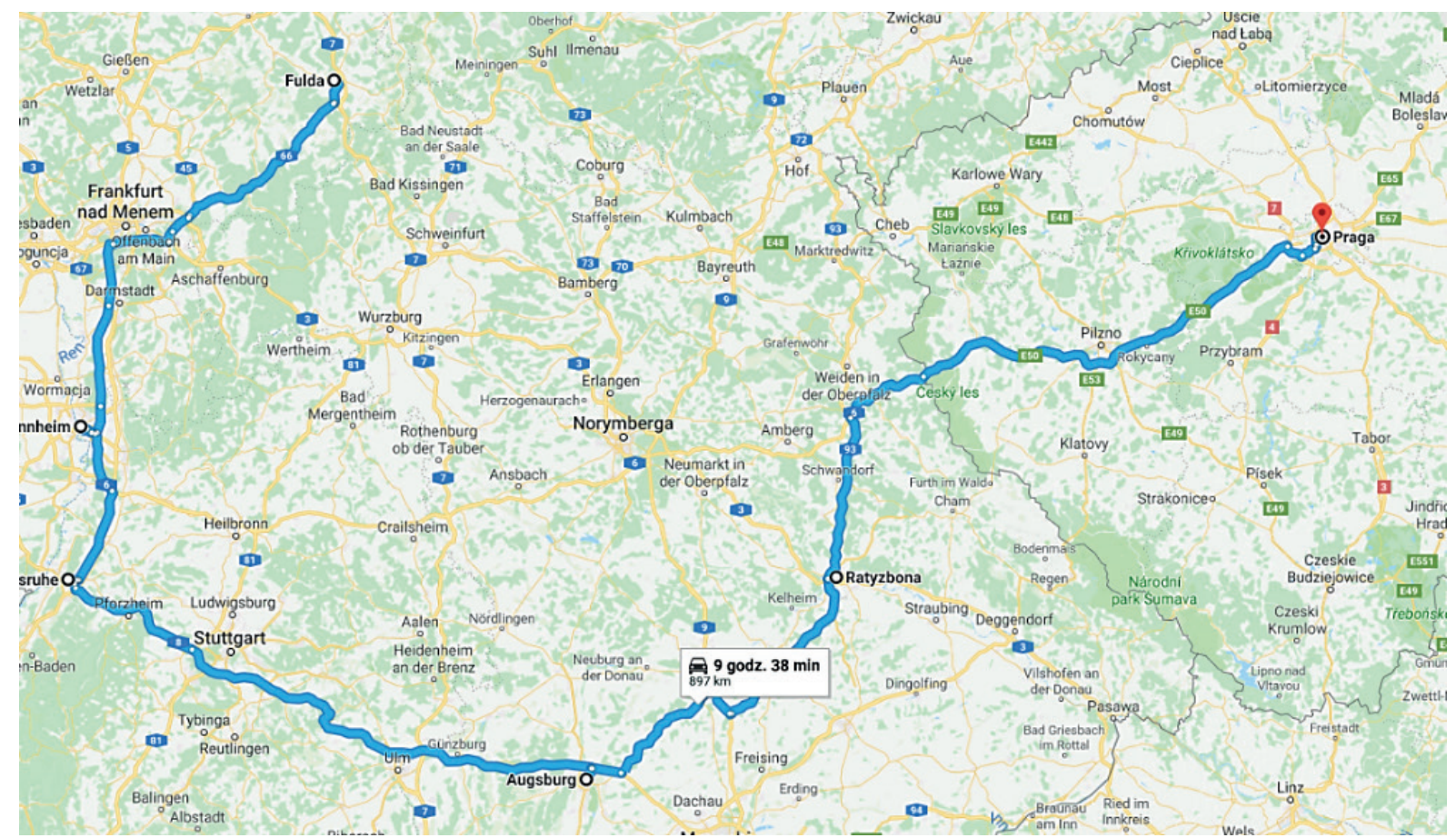

Figure 3 Current organization of transport of a client B - means of transport no. 2 (based on Google Maps pl)

Table 5 The average rates for a kilometre for specific cars (the author's own work)

\begin{tabular}{ccccc}
\hline $\begin{array}{c}\text { car type } \\
(\mathrm{t})\end{array}$ & $\begin{array}{c}\text { dimensions } \\
\text { (length / width / height) }(\mathrm{m})\end{array}$ & $\begin{array}{c}0-300 \mathrm{~km} \\
(€ / \mathrm{km})\end{array}$ & $\begin{array}{c}300-800 \mathrm{~km} \\
(€ / \mathrm{km})\end{array}$ & $\begin{array}{c}>800 \mathrm{~km} \\
(€ / \mathrm{km})\end{array}$ \\
\hline 3.5 & $6.0 / 2.4 / 2.7$ & 0.8 & 0.75 & 0.65 \\
6 & $7.2 / 2.4 / 2.7$ & 0.9 & 0.85 & 0.8 \\
24 & $13.6 / 2.5 / 3$ & 1.3 & 1.25 & 1.2 \\
\hline
\end{tabular}


Table 6 The cost of consolidation service for client B - means of transport no. 1, LDM -length of a load box

\begin{tabular}{|c|c|c|c|c|c|c|}
\hline code & city & number of pallets & $\mathrm{LDM}(\mathrm{m})$ & $\operatorname{mass}(\mathrm{kg})$ & handling $(€)$ & transport $(€)$ \\
\hline 33098 & Paderborn & 4 & 1.6 & 400 & 8 & 62.20 \\
\hline 37001 & Gottingen & 1 & 0.4 & 300 & 2 & 45.71 \\
\hline 38440 & Wolfsburg & 2 & 0.8 & 300 & 4 & 49.21 \\
\hline 14467 & Potsdam & 3 & 1.2 & 500 & 6 & 71.08 \\
\hline 8001 & Zwickau & 2 & 0.8 & 800 & 4 & 73.27 \\
\hline \multirow[t]{3}{*}{1099} & Dresden & 1 & 0.4 & 50 & 2 & 15.90 \\
\hline & total & 13 & 5.2 & 2350 & 26 & 317.36 \\
\hline & & utilization of means of transport & $86.67 \%$ & $78.33 \%$ & & $343.36 €$ \\
\hline
\end{tabular}

Table 7 The cost of consolidation service for client B - means of transport no. 2 LDM - length of a load box)

\begin{tabular}{|c|c|c|c|c|c|c|}
\hline code & city & number of pallets & $\mathrm{LDM}(\mathrm{m})$ & mass $(\mathrm{kg})$ & handling $(€)$ & transport $(€)$ \\
\hline 36001 & Fulda & 2 & 0.4 & 200 & 4 & 26.14 \\
\hline 68159 & Mannheim & 3 & 0.6 & 500 & 6 & 55.97 \\
\hline 76131 & Karlsruhe & 2 & 0.8 & 300 & 4 & 41.55 \\
\hline 86150 & Augsburg & 5 & 2 & 1000 & 10 & 86.80 \\
\hline \multirow[t]{3}{*}{93047} & Ratisbon & 6 & 2.4 & 1000 & 12 & 82.44 \\
\hline & total & 18 & 6.2 & 3000 & 36 & 292.94 \\
\hline & & utilization of means of transport & $86.11 \%$ & $78.33 \%$ & & $328.94 €$ \\
\hline
\end{tabular}

Table 8 Delivery time of cargos to Nuremberg (Client B) - means of transport no. 1

\begin{tabular}{|c|c|c|c|c|c|c|c|}
\hline code & city & date & time & code & city & date & time \\
\hline 33098 & Paderborn & 2.07 & 08:00 & 90402 & Nuernberg & 4.07 & 08:00 \\
\hline 37001 & Gottingen & 2.07 & $11: 00$ & 90402 & Nuernberg & 4.07 & 08:00 \\
\hline 38440 & Wolfsburg & 2.07 & $14: 00$ & 90402 & Nuernberg & 4.07 & 08:00 \\
\hline 14467 & Potsdam & 2.07 & $09: 30$ & 90402 & Nuernberg & 4.07 & 08:00 \\
\hline 8001 & Zwickau & 2.07 & $11: 30$ & 90402 & Nuernberg & 4.07 & 08:00 \\
\hline 1099 & Dresden & 2.07 & $15: 00$ & 90402 & Nuernberg & 4.07 & 08:00 \\
\hline
\end{tabular}

Table 9 Delivery time of cargos to Nuremberg (Client B) - means of transport no. 2

\begin{tabular}{|c|c|c|c|c|c|c|c|}
\hline code & city & date & time & code & city & date & time \\
\hline 36001 & Fulda & 2.07 & 08:00 & 90402 & Nuernberg & 4.07 & 08:00 \\
\hline 68159 & Mannheim & 2.07 & $12: 00$ & 90402 & Nuernberg & 4.07 & 08:00 \\
\hline 76131 & Karlsruhe & 2.07 & $14: 00$ & 90402 & Nuernberg & 4.07 & 08:00 \\
\hline 86150 & Augsburg & 2.07 & $19: 30$ & 90402 & Nuernberg & 4.07 & 08:00 \\
\hline 93047 & Ratisbon & 2.07 & $10: 00$ & 90402 & Nuernberg & 4.07 & 08:00 \\
\hline
\end{tabular}

Table 10 Transport of consolidated cargo to Prague

\begin{tabular}{|c|c|c|c|c|c|c|c|}
\hline code & city & date & time & code & city & date & time \\
\hline 90407 & Nuernberg & 4.07 & 09:00 & 10000 & Praga & 4.07 & $13: 30$ \\
\hline
\end{tabular}

terms of postal code of a supplier, the rate of reception of all suppliers and for handling operations is $343.36 €$ Client B - means of transport no. 1, and for Client B means of transport no. 2 is $328.95 €$. Total cost of movements for client B is $1604.3 €$ per week (Table 11).

There is one issue to be determined yet, the impact of extended transit on the costs frozen in material. The value of cargo and number of production days of the plant are needed. The value of goods is forty-five thousand euro, in six-day production line; it is seven and a half thousand euros a day. Increasing the transit by one day will give negative impact for value of one day, that is, seven and a half thousand euro. Comparing the losses in material and savings in transport, one gets a positive result in 


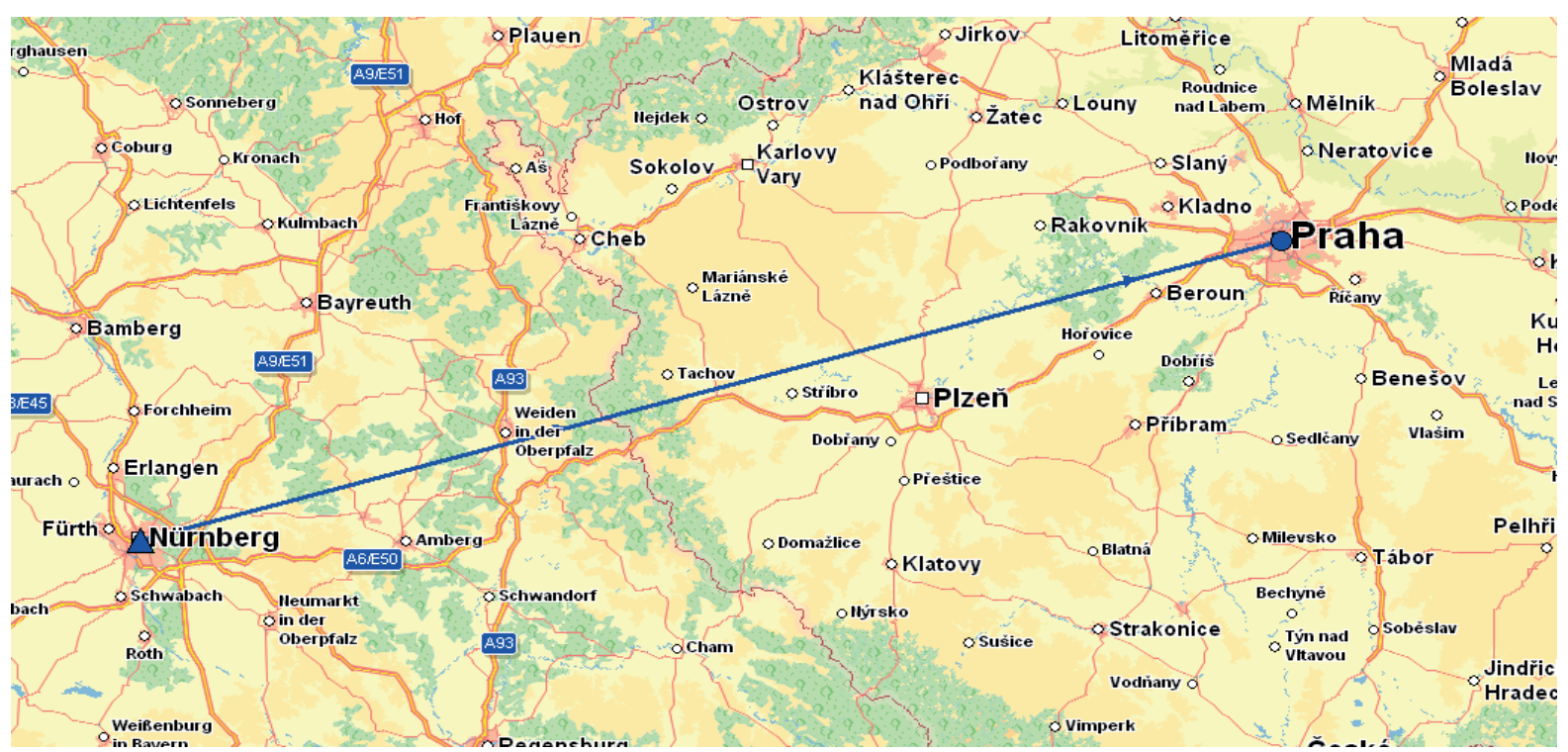

Figure 4 Nuremberg - Prague (based on use of the Optimizing XYZ)

Table 11 The savings of a client B, proposed offer of a transport enterprise

\begin{tabular}{lcccc}
\hline route & type of a car $(\mathrm{t})$ & distance & feet & costs $(€)$ \\
\hline suppliers -> client B Prague 1 & 3.5 & 1018 & 5 & 786.70 \\
suppliers -> client B Prague 2 & 6 & 897 & 4 & 817.60 \\
actual total cost & & & 1604.30 \\
suppliers -> Nuremberg 1 & consolidation & & 343.4 \\
suppliers -> Nuremberg 2 & consolidation & 300 & 328.9 \\
Nuremberg -> client B Prague & 24 & & 390 \\
proposed total cost & & & 1062.31 \\
weekly saving & & & -541.99 \\
annual saving & & & -26015.75 \\
\hline
\end{tabular}

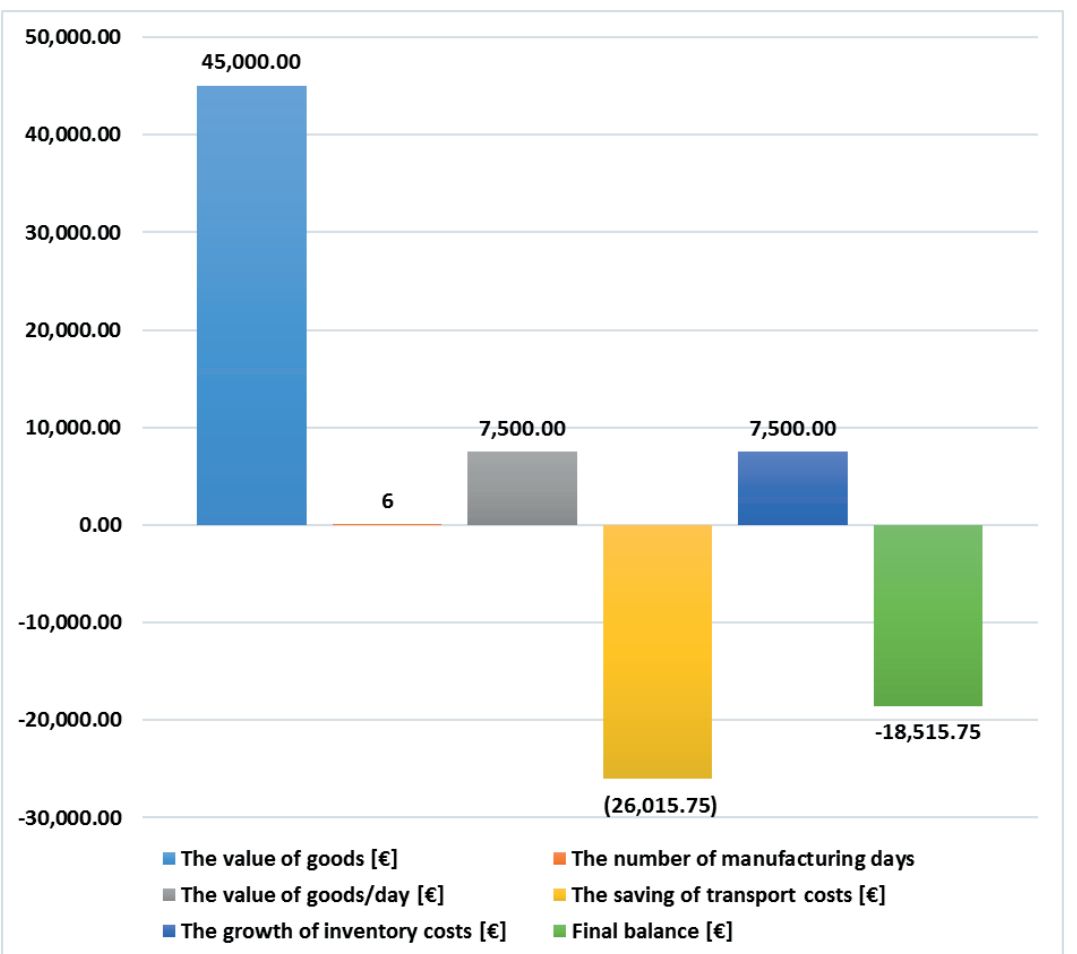

Figure 5 Comparison of transport savings and inventory losses of a client $B$ 
the form of thirty thousand euros of saving for client B (Figure 5).

\section{Conclusions}

The fundamental goal of the authors of this article was to determine the role of reduction of transport costs with the use of consolidation service. To achieve the goal, execution of the following plans was used:

- An analysis of current transport organization of a client,

- An assignment of particular suppliers to warehouses towards terminal network of a transport enterprise providing consolidation services,

- Calculation of costs of consolidation service, taking transport and handling costs into account,
- Determination of the impact of transport organization on inventory costs,

- Comparison of current costs with proposed solution,

Conducted analysis allowed to prove that consolidation services reduce the costs of transport of small cargos. In the event of direct transports, the cars must cover many kilometres, only to take one small parcel or pallet. Medium and large cargos are not cost-effective for such organizations, however, direct and consolidation method can be combined to get the optimal results. Impact on inventory costs was also taken into consideration in the analysis. Extended time of transit, caused by use of a consolidation service, should be in majority of cases covered by the transport savings.

\section{References}

[1] HANBAZAZAH, A. S., ABRIL, L., ERKOC, M., SHAIKH, N. Freight consolidation with divisible shipments, delivery time windows, and piecewise transportation costs. European Journal of Operational Research [online]. 2019, 276(1), p. 187-201. ISSN 0377-2217. Available from: https://doi.org/10.1016/j.ejor.2018.12.043

[2] BOOKBINDER, J. H., ELHEDHLI, S., LI, Z. The air-cargo consolidation problem with pivot weight: models and solution methods. Computers and Operations Research [online]. 2015, 59(C), p. 22-32. ISSN 0305-0548. Available from: https://doi.org/10.1016/j.cor.2014.11.015

[3] CROXTON, K. L., GENDRON, B., MAGNANTI, T. L. Models and methods for merge-in-transit operations. Transportation Science [online]. 2003, 37(1), p. 1-22. ISSN 0041-1655, eISSN 1526-5447. Available from: https://doi.org/10.1287/ trsc.37.1.1.12822

[4] KOLINSKI, A., STAJNIAK, M. Effectiveness of transport processes: modern problems and development trends / Efektywnosc procesow transportowych: wspolczesne problemy i trendy rozwoju (in Polish). Radom: Instytut Naukowo-Wydawniczy, 2016. ISBN 978-83-62805-18-1.

[5] NOWACKI, G., KRYSIUK, C., NIEDZICKA, A. Selected transport problems of dangerous goods in the European Union and Poland. In: Safety of Marine Transport. 2015. ISBN 978-1-138-02859-3, eISBN 978-1-315-67261-8, p. 297-303.

[6] QIN, H., ZHANG, Z., QI, Z., LIM, A. The freight consolidation and containerization problem. European Journal of Operational Research [online]. 2014, 234(1), p. 37-48. ISSN 0377-2217. Available from: https://doi.org/10.1016/j. ejor.2013.09.015

[7] FAN, Y., BEHDANI, B., BLOEMHOF- RUWAARD, J., ZUIDWIJK, R. Flow consolidation in hinterland container transport: an analysis for perishable and dry cargo. Transportation Research Part E: Logistics and Transportation Review [online]. 2019, 130, p. 128-160. ISSN 1366-5545. Available from: https://doi.org/10.1016/j.tre.2019.08.011

[8] LV, B., YANG, B., ZHU, X., LI, J. Operational optimization of transit consolidation in multimodal transport. Computers and Industrial Engineering [online]. 2019, 129, p. 454-464. ISSN 0360-8352. Available from: https://doi.org/10.1016/j. cie.2019.02.001

[9] OLSSON, J., WOXENIUS, J. Localisation of freight consolidation centres serving small road haulers in a wider urban area: barriers for more efficient freight deliveries in Gothenburg. Journal of Transport Geography [online]. 2014, 34, p. 25-33. ISSN 0966-6923. Available from: https://doi.org/10.1016/j.jtrangeo.2013.10.016

[10] NEUMANN, T. Fuzzy routing algorithm in telematics transportation systems. In: Smart solutions in today's transport [online]. MIKULSKI, J. (ed.). TST 2017. Communications in computer and information science. Vol. 715. Cham: Springer International Publishing, 2017. ISBN 978-3-319-66250-3, eISBN 978-3-319-66251-0, p. 494-505. Available from: https://doi.org/10.1007/978-3-319-66251-0_40

[11] NEUMANN, T. Automotive and telematics transportation systems. In: International Siberian Conference on Control and Communications SIBCON 2017: proceedings. IEEE, 2017. ISBN 978-1-5090-1081-3, p. 1-4.

[12] KLINCEWICZ, JOHN, G. Solving a freight transport problem using facility location techniques. Operations Research [online]. 1990, 38(1), p. 99-109. ISSN 0030-364X, eISSN 1526-5463. Available from: https://doi.org/10.1287/opre.38.1.99

[13] KUSMINSKA-FIJALKOWSKA, A, KOZYRA, J, OLSZANSKA, S. Analysis of movements of TEU intermodal transshipment terminal in the area of polish. In: International Conference Transport Means: proceedings. 2018. ISSN 1822-296 X, eISSN 2351-7034, p. 849-854. 
[14] MOCCIA, L., CORDEAU, J.-F., LAPORTE, G., ROPKE, S., VALENTINI, M. P. Modeling and solving a multimodal transportation problem with flexible-time and scheduled services. Networks [online]. 2011, 57(1), p. 53-68. eISSN 1097-0037. Available from: https://doi.org/10.1002/net.20383

[15] KUSMINSKA-FIJALKOWSKA, A. Aspect of time in automated processes of TEU flow in a handling terminal / Aspekt czasu w zautomatyzowanych procesach przeplywu TEU w terminalu przeladunkowym (in Polish). Radom: Wydawnictwo UTH, 2018. ISBN 9788373518490.

[16] HAJDUL, M., STAJNIAK, M., FOLTYNSKI, M. KOLIKOWSKI, A., ANDRZEJCZYK P. Organization and monitoring of transport processes / Organizacja i monitorowanie procesow transportowych (in Polish). Poznan: Instytut Logistyki i Magazynowania, 2015. 